\title{
Evi1 forms a bridge between the epigenetic machinery and signaling pathways
}

\author{
Akihide Yoshimi and Mineo Kurokawa \\ ${ }^{1}$ Department of Hematology \& Oncology, Graduate School of Medicine, University of Tokyo, Tokyo, Japan \\ Correspondence to: Mineo Kurokawa, email: kurokawa-tky@umin.ac.jp \\ Keywords: Evil, Leukemia, Polycomb, PTEN, Rapamycin
}

Received: July 5, 2011,

Accepted: July 21, 2011

Published: July 26, 2011

Copyright: (c) Yoshimi et al. This is an open-access article distributed under the terms of the Creative Commons Attribution License, which permits unrestricted use, distribution, and reproduction in any medium, provided the original author and source are credited.

ABSTRACT:

\begin{abstract}
Recent studies have demonstrated the significance of the leukemia oncogene Evi 1 as the regulator of hematopoietic stem cells and marker of poor clinical outcomes in myeloid malignancies. Evi1-mediated leukemogenic activities include a wide array of functions such as the induction of epigenetic modifications, transcriptional control, and regulation of signaling pathways. We have recently succeeded in comprehensively elucidating the oncogenic function of Evi1 in a model of the polycomb-Evi1-PTEN/ AKT/mTOR axis. These results may provide us with novel therapeutic approaches to conquer the poor prognosis associated with Evi1-activated leukemia or other solid tumors with high Evi1 expression. Here, we review the current understanding of the role of Evi1 in controlling the development of leukemia and highlight potential modalities for targeting factors involved in Evi1-regulated signaling.
\end{abstract}

\section{INTRODUCTION}

Ecotropic viral integration site 1 (Evi1) is a nuclear zinc finger protein that is essential for the proliferation and maintenance of hematopoietic stem cells (HSC) [1]. Clinically, activated Evil expression is observed in approximately $10 \%$ of patients with acutemyeloid leukemia (AML) and is an independent factor associated with poor prognosis in AML [2-4]. Evi1 is located on chromosome $3 q 26$, and the up-regulation of Evi1 expression was originally found to be a consequence of inv(3)(q21q26.2) or $\mathrm{t}(3 ; 3)(\mathrm{q} 21 ; \mathrm{q} 26.2)[5,6]$. In addition, we have recently shown that Evi1 is transcriptionally up-regulated by oncogenic MLL fusion proteins [7]; around half of the patients with AML having 11q23 rearrangements display high Evil expression [2]. Chromosomal abnormalities involving chromosome 7 are another candidate cause of Evil activation [2,8]. Molecularly, Evi1 has a variety of functions as an oncoprotein. Firstly, it regulates some signaling pathways. The most characterized function is the negative control exerted by Evil on TGF- $\beta$ signaling through the repression of Smad3 function by physical interaction and recruitment of the corepressor CtBP $[9,10]$; this may contribute to the leukemogenic activity of Evil by promoting cellular proliferation and affecting cellular differentiation. Moreover, Evil exerts anti-apoptotic effects by suppressing the JNK1-mediated phosphorylation of c-Jun [11] or inhibiting interferon- $\alpha$ signaling through the regulation of the $P M L$ gene [12]. Secondly, Evil has been shown to act as a transcriptional factor and regulate the expression of several target genes by directly binding DNA through its proximal zinc finger domain and recognizing a consensus sequence consisting of $\mathrm{GA}(\mathrm{C} / \mathrm{T}) \mathrm{AAGA}(\mathrm{T} / \mathrm{C}) \mathrm{AAGATAA}-$ like or GACAAGATA-like motifs $[13,14]$. We and other groups have reported that Evil regulates GATA2 [14], PBX1 [15], and PML [12] transcription. Thirdly, recent studies have indicated that Evil actively induced epigenetic changes by interacting with various molecules. In this perspective, we will discuss the novel oncogenic functions of Evi1, particularly focusing on the relationship between leukemogenesis and epigenetics or signaling pathways.

\section{EPIGENETICS IN LEUKEMOGENESIS}

Although cancer development has been considered a consequence of genetic changes, it has become increasingly evident that it also involves epigenetic changes that are mechanisms affecting gene expression profiles without alterations in the DNA sequence. Such mechanisms include DNA methylation, histone modification, and microRNA involvement. In 
hematological malignancies, recent findings of frequent mutations in epigenetic regulators such as EZH2 [16-18], DNMT3A [19-21], TET2 [22,23], ASXL1 [24], and UTX [25] support the idea that dysregulation of epigenetics plays a role in leukemogenesis [26,27]. For example, somatic mutations in EZH2 are frequently identified in myeloid malignancies, particularly in myelodysplastic syndrome and myeloproliferative neoplasms [16-18]. $\mathrm{EZH} 2$ is a core component of the polycomb repressive complex 2 (PRC2) and catalyzes histone 3 lysine 27 (H3K27) trimethylation in association with SUZ12 and EED. Another complex called PRC1 possesses histone 2A lysine 119 E3 ubiquitin ligase activities, and these histone modifications are essential for the silencing of polycomb target genes, which in turn regulate a broad array of biological processes such as the cell cycle, apoptosis, stem cell regulation, senescence, and cancer development [2832]. Most of the missense mutations of EZH2 occurred in the CXC-SET domain and domain II, both of which are essential for the histone methyltransferase activity. Therefore, truncated or missense mutations in EZH2 observed in myeloid malignancies are supposed to be inactivating mutations [16], and EZH2 may be a tumor suppressor in this context. On the other hand, intact polycomb group (PcG) proteins function as oncogenic silencers in other contexts, as shown below.

\section{EVI1 LINKS THE EPIGENETIC MACHINERY TO THE REGULATION OF ITS TARGET GENE/SIGNALING PATHWAY}

We have recently found that Evil physically interacts with PcG proteins (EZH2, SUZ12, EED, BMI1, RING1, RING2, and HPH2) [33]. However, it appeared that Evil expression did not affect the global methylation status of H3K27 (data not shown). This finding prompted us to investigate specific target genes of Evil whose expressions were repressed in concert with PcG proteins. Our microarray data using primary bone marrow (BM) progenitors with forced expression of Evil and some sets of published gene expression data from AML samples $[4,34]$ were combined and bioinformatically analyzed, leading to the identification of the tumor suppressor PTEN as a novel repressive target of Evi1. Chromatin immunoprecipitation (ChIP) assays using Evil-transduced BM cells indicated that Evil induced $\mathrm{H} 3 \mathrm{~K} 27$ trimethylation marks on the PTEN genomic locus by recruiting PcG proteins. As PTEN is a well-established tumor suppressor and acts as a negative regulator of the PI3K/AKT pathway, and we found that Evil activated the AKT/mTOR signaling pathway through transcriptional repression of PTEN. The activation of this signaling is essential for Evil-mediated leukemogenesis, as discussed later. Interestingly, RNAi- mediated knockdown of EZH2 restored PTEN expression and down-regulated the AKT/mTOR activities in Eviltransduced BM cells, suggesting that Evil functions as a platform to recruit $\mathrm{PcG}$ proteins to the PTEN locus (Figure 1). In accordance with the aforementioned concept, the effects of EZH2 knockdown on PTEN expression were not observed in BM cells with low Evil expression. In other words, EZH2 can act as an oncoprotein in the presence of high Evil expression. Another example of the oncogenic function of EZH2 has been investigated in acute promyelocytic leukemia (APL). APL is induced by a differentiation block and an overgrowth of promyelocytes attributed to chromosomal translocation, leading to the production of fusion proteins such as PML/RAR $\alpha$ and PLZF/RAR $\alpha$. These chimeric proteins have been shown to recruit PcG complexes to the target gene promoters through the RAR $\alpha$ moiety and block cell differentiation $[35,36]$. Therefore, such oncogenic functions of $\mathrm{PcG}$ proteins can be therapeutic targets (Figure 1). In addition, we confirmed that Evil-transduced BM cells show specifically increased sensitivity to a PRC2 inhibitor [3-Deazaneplanocin A (DZNep)] (data not shown).

Increasing evidence indicating the involvement of Evil in the epigenetic regulation of gene transcription has been recently accumulated. Lugthart et al. have shown that AML samples with activated Evil presented with a deregulated hypermethylation signature, possibly through physical interactions between Evil and the DNA methyltransferases DNMT3A and DNMT3B [37]. Their genome-wide DNA methylation profiling revealed about 300 promoters (out of the 14000 tested) with abundant cytosine methylation, and ChIP assays for the purpose of validation identified some Evil target genes such as FAM 83 b CRHBP, VPREB3, and IL11RA. Given that EZH2 has been reported to interact with DNMT3A and DNMT3B [38], the two reports on Evil and histone/ DNA methyltransferases may support each other in demonstrating that Evi1 repressed target gene transcription through, at least in part, PcG-DNMT complex-mediated epigenetic modifications.

BesidesPcGproteinsandDNMTs, weandothergroups have demonstrated that Evil recruits epigenetic regulators for controlling transcription. For example, SUV39H1 and G9a are H3K9 methyltransferases associated with gene silencing $[39,40]$, and they also interact with Evil [41-43]. Reporter assays have indicated that SUV39H1 synergistically suppressed the transcriptional activity of Evi1, and knockdown of SUV39H1 or G9a specifically reduced the colony-forming activity of Evil-transduced $\mathrm{BM}$ cells, suggesting that H3K9 methyltransferases are actively involved in Evil-associated oncogenic functions, possibly through the epigenetic repression of putative Evil target genes. In addition, Evil physically associated with the methyl-CpG binding protein $3 b$ [44] and histone deacetylases 1 [45], both of which are the core components of the NuRD complex that harbors 


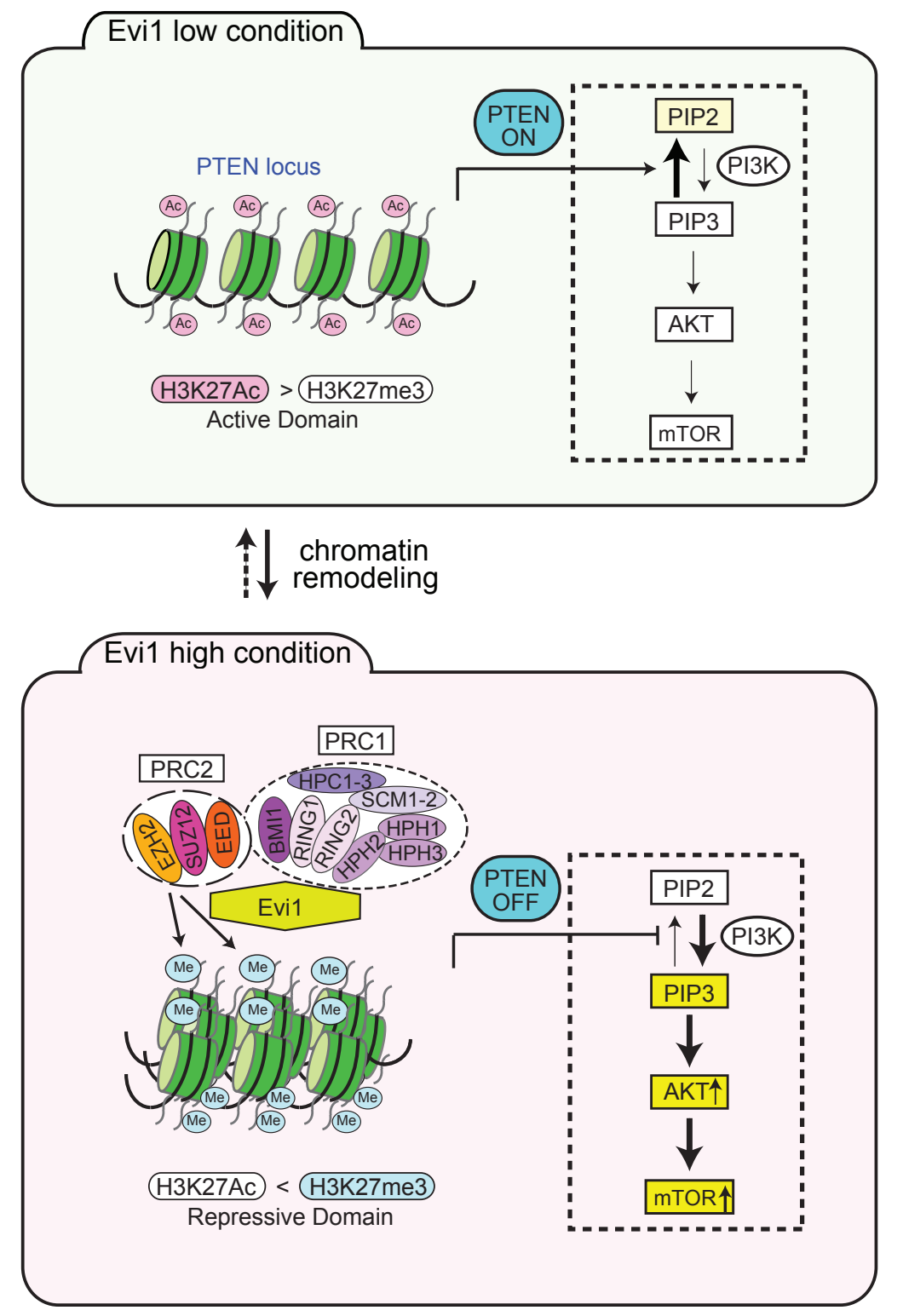

Figure 1:Evi1 induces epigenetic regulation on PI3K/PTEN/AKT/mTOR signaling. In cells with high Evi1 expression, Evi1 recruits polycomb repressive complexes (PRC1 and PRC2) to the PTEN locus and epigenetically represses PTEN transcription, which in turn stimulates AKTand mTOR. These regulatory mechanisms are activated only in cells with high Evil expression.

histone deacetylase activity and induces transcriptional repression [46,47]. Evi1 associates with Brahma-related gene 1 (BRG1; also known as SMARCA4 and SNF2 $\beta$ ), a member of the SWI/SNF chromatin-remodeling complex [48]. In reporter assays, the authors have shown that Evil activated the E2F1 promoter in association with BRG1, which suggested that Evil enhanced cell cycling and cellular proliferation through the up-regulation of E2F1 by interacting with the SWI/SNF complex. Taken together, these data suggest that Evil has the potential to induce transcriptional repression by recruiting higher order chromatin remodeling complexes.

Along with chromatin remodeling factors, microRNAs play a part in epigenetic regulation, and recent findings have clarified that Evil regulates some
microRNAs. Dickstein et al. have demonstrated that Evil silenced miRNA-124 expression through the methylation of CpGs located around miRNA-124 [49]. In addition, they have shown that Evil induction in $\mathrm{Lin}^{-}$murine $\mathrm{BM}$ cells increased the expression of BMI1 and cyclin D3, whereas forced expression of miRNA-124 in Eviltransduced murine BM cells restored their expression. Furthermore, Gomez-Benito et al. have recently shown that Evil directly bound to the miR-1-2 promoter region and up-regulated its expression, which may have a role in the Evil-mediated proliferation activity, as shown by transient transfection assays using AML cell lines [50]. Likewise, Evil has been suggested to increase K-ras oncoprotein expression through the direct repression of miR-143 in colon cancer [51]. The authors argued 
that the Evi1/miR-143/K-ras axis contributed to colonic carcinogenesis by enhancing proliferation capacity and motility.

These data strongly suggest that Evil regulates target gene transcription by mobilizing epigenetic mechanisms.

\section{PI3K/AKT/MTOR SIGNALING IN EVI1- MEDIATED LEUKEMOGENESIS}

Next, we focused on the PI3K/PTEN/AKT/mTOR signaling pathway in leukemia (overviewed in Figure 2; see other review articles such as [52-54] for more detailed information). As presented above, Evil recruited polycomb complexes to the PTEN genomic locus and activated the AKT/mTOR signaling pathway through the transcriptional repression of PTEN [33]. On the basis of these observations, we established a murine AML model with high Evil expression by BM transplantation and aimed to test the efficacy of the mTOR inhibitor rapamycin on the leukemia model in vivo. Administration of rapamycin significantly prolonged the survival of diseased mice, suggesting that the AKT/mTOR pathway played a role in the proliferation and survival of the Evil-expressing AML cells. Moreover, we investigated the effects of rapamycin on other leukemia models established by transduction of the AML1 mutant (AML1_S291fsX300) [55] and coexpression of TEL/PDGF $\beta$ R and AML1/ETO [56] and found no changes in their survival; this demonstrated the specific sensitivity of Evil-activated leukemia cells to rapamycin (Figure 1).

Extensive studies regarding $\mathrm{PI} 3 \mathrm{~K} / \mathrm{AKT} / \mathrm{mTOR}$ signaling and leukemia have demonstrated that PI3K/ AKT signaling is frequently activated in AML $[57,58]$. In particular, AKT phosphorylation on Ser473 was detected in over half of the patients with AML [57]. As demonstrated by Tamburini et al. and Xu et al., downstream mTORC1 is constitutively activated in primary AML samples [58,59]. However, the mechanisms of PI3K/AKT/mTORC1 activation remain largely unclear. PTEN and SHIP are negative regulators of PIP3 and downstream AKT/mTOR signaling. Xu et al. have shown that PTEN expression was down-regulated in a few patients with AML, but PTEN expression levels were not inversely correlated with AKT phosphorylation levels for an unknown reason [58]. Gene mutation analysis of PTEN and SHIP has revealed that mutations in these genes are uncommon [60,61] although a SHIP-V684E mutation was found in one out of 30 patients with AML. This mutation reduced catalytic function and enhanced AKT phosphorylation, which may contribute to leukemogenesis [61]. On the other hand, PTEN phosphorylation levels have been analyzed in AML. Phosphorylated PTEN was positively correlated with AKT phosphorylation (Figure 2) and was found

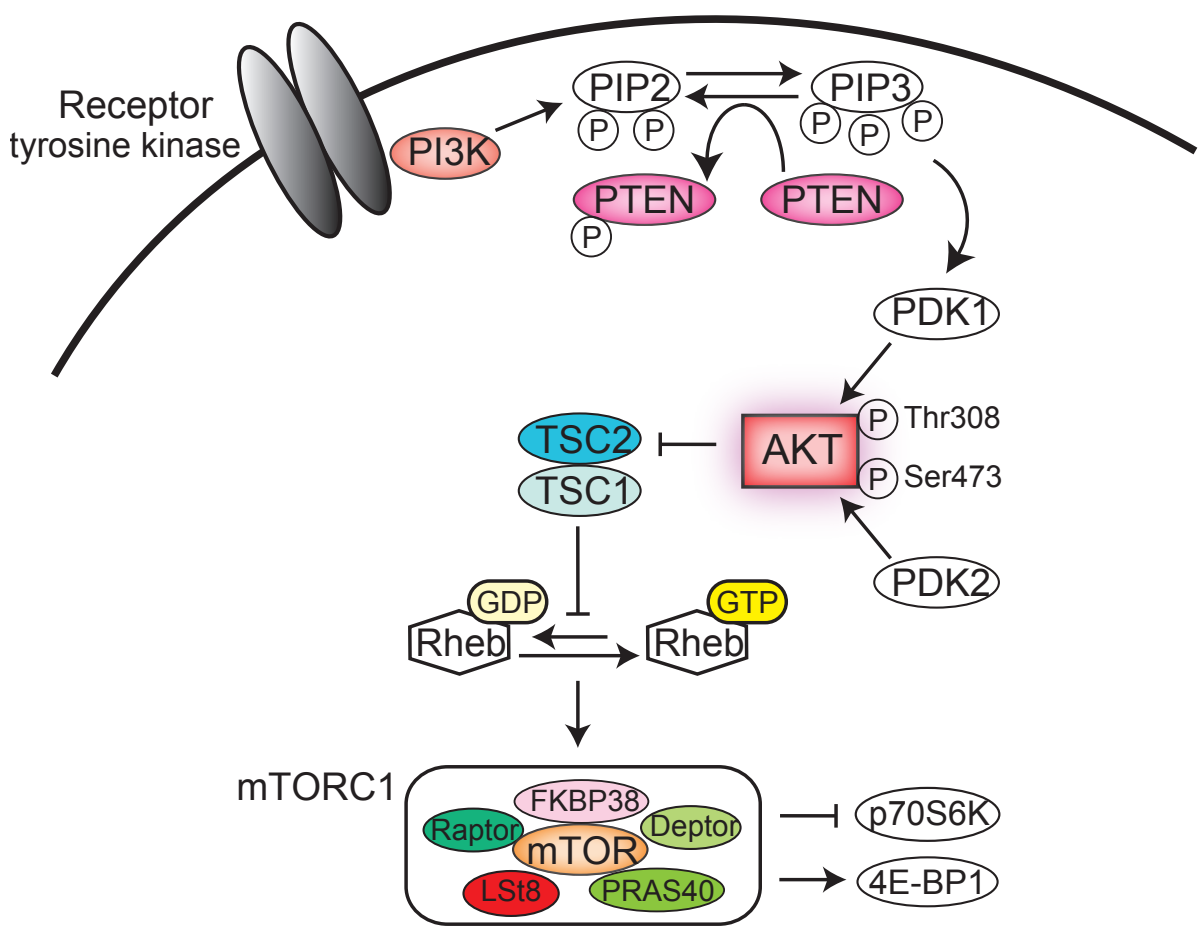

Figure 2:The PI3K/PTEN/AKT/mTORC1 pathway. An activated tyrosine kinase receptor induces class IA PI3K activation, which in turn phosphorylates the lipid phosphatidyl-inositol bisphosphate (PIP2) to generate phosphatidyl-inositol triphoshate (PIP3). PIP3 recruits PDK1 and AKT to the plasma membrane, where PDK1 phosphorylates AKT on Thr308. The phosphorylation of AKT on Ser473 is mediated by PDK2 and controls AKT activity. AKT phosphorylates a wide variety of substrates, including FOXO transcription factors, Bad, p27 $7^{\mathrm{kip} 1}$, p21Cip, GSK-3 $\beta$, MDM2, and TSC2. AKT-driven TSC1/TSC2 complex inactivation leads to the accumulation of GTP-bound Rheb. Rheb-GTP then activates mTORC1. mTORC1 regulates protein synthesis by regulating p70S6K and 4E-BP1. In this pathway, PTEN phosphatase acts as a negative regulator through dephosphorylation of PIP3 at the 3'position. 
in $74 \%$ of patients with AML [62]. The authors have demonstrated that phosphorylated PTEN is a predictor of clinical outcome in patients with AML.

With regard to PI3K/PTEN/AKT signaling as a prognostic factor, some controversial results have been reported by several groups. Min et al. have shown that phosphorylation of AKT on Ser473 and Thr308 confers poor prognosis in AML [63]. Kornblau et al. have shown similar results using a Ser473-specific antibody ([64] and personal communication with S. Kornblau). Meanwhile, Tamburini et al. have evaluated as many as 188 patients and demonstrated that constitutive activation of PI3K was associated with better prognosis [57]. Furthermore, Gallay et al. have shown that AKT phosphorylation on Thr308, but not on Ser473, predicted an adverse outcome in AML [65]. These complicated data may be partly explained by the heterogeneity of leukemic cells used in evaluating PI3K/ AKT phosphorylation $[57,63,64]$. Intracellular FACS staining and antibodies of high quality have enabled us to measure the phosphorylation status of a small amount of cells such as an immature population with $\mathrm{CD} 34^{+}, \mathrm{CD} 38^{-}$, and $\mathrm{CD} 123^{+}$phenotypes, wherein leukemia stem cells (LSCs) are supposed to be enriched $[65,66]$. Given that the PTEN/AKT/mTOR pathway plays an essential role in leukemia-initiating cells $[67,68]$, the evaluation of this pathway in a purified leukemia population may provide some important insights. In addition, the aforementioned discrepancy may be attributed to the existence of crossactivation with other pathways or feedback systems in leukemic cells, as shown by Kornblau et al. that ERK and PKC $\alpha$ were more likely to be activated in leukemic cells with AKT phosphorylation than statistically expected ([64]; Excellent reviews on the cross-talk among the RAF/ MEK/ERK, PI3K/PTEN/AKT/mTOR, and JAK/STAT pathways are available: $[69,70])$.

Our experimental model using murine primary BM has allowed the demonstration of one of the possible mechanisms of AKT/mTOR activation through PTEN repression in AML. We confirmed an inverse correlation between Evil and PTEN mRNA expression levels in human AML and chronic myeloid leukemia (CML) samples but have not checked the status of AKT/ mTOR signaling. Thus, these data suggest the need for investigating whether Evil-mediated AKT/mTOR activation in mice is recapitulated in human leukemia. Large scale studies applying a proteomic approach to human leukemic samples will provide comprehensive insight into the regulation of signaling pathways.

\section{HSC, LSC, AND THE EVI1-PTEN AXIS}

Pten depletion in murine adult hematopoietic cells has caused short-term HSC expansion and long-term depletion of the HSC pool $[67,68]$. When Pten-deficient HSCs were transplanted into recipient mice, they could not reconstitute multilineage hematopoiesis. Moreover, Pten depletion has been shown to induce myeloproliferative neoplasms and their progression to acute leukemia, which may partly be a reflection of genomic instability [71]. Yilmaz et al. have demonstrated that rapamycin restored normal HSC function and effectively depleted leukemiainitiating cells simultaneously [67], suggesting that mTOR plays a significant role downstream of the PI3K/PTEN/ AKT axis and can be an ideal therapeutic target.

Given that Evil is essential for HSC proliferation and myeloid leukemia cells [1], the Evi1-PTEN axis may potentially contribute to HSC and LSC regulation. Peng et al. have shown that $\mathrm{BCR} / \mathrm{ABL}$ repressed PTEN in CML, and this repression was important for leukemogenesis $[72,73]$. The authors isolated $\mathrm{Lin}^{-}, \mathrm{ckit}^{+}$, and $\mathrm{Scal}^{+}$cells from BCR/ABL-induced and both BCR/ABL and PTENinduced CML mice and transplanted the same number of each leukemic cell into the secondary recipient mice. The survival of the mice receiving LSCs transduced with both $\mathrm{BCR} / \mathrm{ABL}$ and PTEN was significantly longer than that of the control mice, indicating that PTEN negatively regulated LSC functions. These results are consistent with our expression profiling of human CML samples showing an inverse correlation between Evil and PTEN levels and a tendency of Evil to be activated as the disease progresses from the chronic phase to blastic crisis [33]. Therefore, the Evil-PTEN axis may play a role in LSC functions and the progression of leukemia.

\section{RAPAMYCIN MAY ACT AS A MULTI- FUNCTION AGENT IN A RECIPIENT OF ALLOGENEIC HSCT}

Rapamycin binds to the FK506 binding protein 1A to form an immunosuppressive complex that inhibits mTOR and exerts antiviral, antifungal, antineoplastic, and immunosuppressive properties $[74,75]$. On the basis of the antineoplastic activities in preclinical studies, the efficacy of rapamycin (Sirolimus; Wyeth, Collegeville, PA, USA) and its analogs (rapalogs) has been investigated in clinical trials for the treatment of leukemia or lymphoma, and promising results have begun to be reported [76-86]. For instance, Recher et al. have shown that rapamycin achieved significant clinical response against four out of nine patients with either refractory/relapsed de novo AML or refractory secondary AML [87]. In addition to its antineoplastic efficacy, rapamycin suppresses T-cell proliferation/activation and has been used in the treatment of graft versus host disease (GVHD) after allogeneic hematopoietic stem cell transplantation (HSCT) [74,77,78,88-94]. In allogeneic HSCT for patients with lymphoma, a retrospective study comparing the outcome of GVHD prophylaxis between rapamycin-containing regimens and a combination of calcineurin inhibitor and methotrexate without rapamycin was conducted [95]. Intriguingly, the use of rapamycin significantly decreased disease progression without any differences in nonrelapse 
mortality in patients who underwent reduced-intensity conditioning regimens. This suggested that rapamycin can serve the dual purpose of an immunosuppressant and an antineoplastic agent. In addition, several reports have suggested the possibility that rapamycin exerts inhibitory effect on GVHD without interfering with graft versus leukemia(GVL) effect [96,97] (Figure 3). Moreover, Marty et al. reported that rapamycin-based GVHD prophylaxis reduced cytomegalovirus reactivation [98], which is still one of the challenging problems in HSCT because of the toxicity of cytomegalovirus itself or ganciclovir treatment-related toxicities such as myelosuppression and consequent risk of graft failure. On the other hand, the use of rapamycin or its analog, everolimus, may increase the risk of sinusoidal obstruction syndrome (veno-occlusive disease) under certain situations and lead to renal dysfunction, encephalopathy, and multiple organ failure, which is associated with high mortality $[99,100]$. Thus, the outcomes of large prospective trials that multilaterally evaluate the efficacy and toxicity of these agents in the treatment of leukemia and allogeneic HSCT are awaited.

\section{CONCLUSIONS AND FUTURE DIRECTIONS}

Recent extensive studies have greatly increased our understanding of the roles of epigenetic regulation and signaling pathways in normal and malignant cells at the molecular level. These studies have demonstrated that the leukemia proto-oncoprotein Evil formed a bridge between the epigenetic machinery and signaling pathways and proposed therapeutic targets for the eradication of
Evil-related myeloid malignancies.

Recent studies have demonstrated that Evil is a strong inducer of epigenetic regulation of multiple genomic regions in hematopoietic cells. Clinical trials targeting patients with hematological malignancies have shown some efficacies and limitations of epigenetic agents such as histone deacetylase inhibitors and DNA methyltransferase inhibitors (reviewed in [101-105]). However, whether these drugs have the capacity to specifically counteract Evil-mediated leukemogenic activity is unclear. Considering the marked clinical heterogeneity of hematological malignancies, accumulation of the results of epigenetic therapies on the basis of molecularly defined clusters will be essential for the appropriate use of epigenetic drugs. Efficient attenuation of the epigenetic regulators involved in Evi1mediated transcriptional silencing potentially restores the expression of several possible tumor suppressors and improves the extremely poor prognosis of leukemia with activated Evil.

Song et al. have recently reported that BMI1 induced epithelial-mesenchymal transition partially through transcriptional repression of PTEN in nasopharyngeal epithelial cells (NPECs) [106]. These results and those of our study have suggested that PcG proteins can target PTEN/AKT/mTOR signaling under specific circumstances. Our study proposes that one such condition in the hematopoietic system is high Evil activity because PcG proteins did not affect PTEN transcription in hematopoietic cells with low Evil expression. Meanwhile, it is yet to be determined whether anchor proteins like Evil are required in BMI1-mediated PTEN regulation in NPEC or other cells. Interestingly, a recent genome association

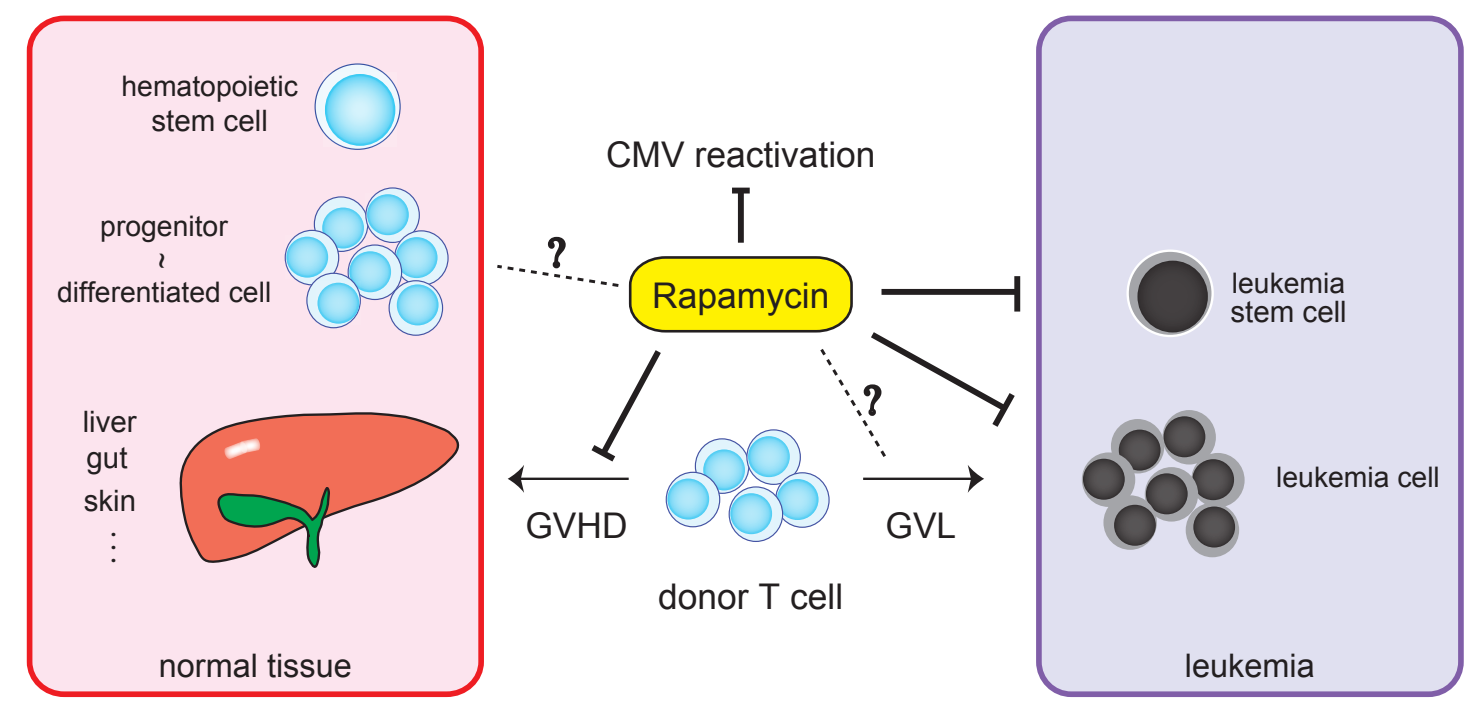

Figure 3: Rapamycin may act as a multi-function agent in a recipient of allogeneic hematopoietic stem cell transplantation. Rapamycin exerts multiple functions including antineoplastic, immunosuppressive, and antiviral properties via inhibition of mTOR. In a recipient of allogeneic hematopoietic stem cell transplantation, rapamycin has a direct anti-leukemic potential. In addition, rapamycin can act as an immunosuppressive agent against graft versus host disease (GVHD) without impairing graft versus leukemia (GVL) effect. Rapamycin has been reported to reduce cytomegalovirus (CMV) reactivation after allogeneic stem cell transplantation. The effect of rapamycin on leukemia stem cells, GVL, or normal graft should be investigated more extensively. 
study of nasopharyngeal carcinoma identified MDS1/Evil on 3q26 as a susceptibility locus [107]. Given that Evi1 has been suggested to be implicated in several carcinomas other than hematopoietic malignancies [107-111], deep insight into the function of Evil with regard to epigenetic regulation and signaling pathways may contribute to the development of molecularly targeted therapies for solid tumors such as colon cancer, lung cancer, nasopharyngeal carcinoma, and ovarian cancer. Particularly, PI3K/AKT signaling is one of the most frequently and aberrantly regulated pathways in human cancer [54,112-114], and Evi1-mediated AKT activation has been demonstrated in colon cancer cells [109]. These reports have suggested that the Evil-AKT axis is involved with several solid tumors. In addition, there is increasing evidence showing aberrantly activated PI3K/AKT/mTORC1 signaling in cancer stem cells, including leukemia as mentioned above [115-119]. Current clinical trials and studies using murine models have shown that rapamycin and rapalogs are less toxic to normal hematopoiesis than they are to malignancies and possibly less toxic to HSC than to LSC. More investigation for this scientific basis will enable us to develop rapamycin-containing therapy targeting AKT/ mTORC1 activity in cancer stem cells.

\section{ACKNOWLEDGMENTS}

We thank Dr. Steven Kornblau for providing us with information about his previous publication. This work was supported in part by grants from the Ministry of Education, Culture, Sports, Science and Technology (KAKENHI 19679004) and by Grants-in-Aid for Scientific Research from the Japan Society for the Promotion of Science for Young Scientists (JSPS) awarded to Akihide Yoshimi.

\section{REFERENCES}

1. Goyama S, Yamamoto G, Shimabe M, Sato T, Ichikawa M, Ogawa S, Chiba S, Kurokawa M. Evi-1 is a critical regulator for hematopoietic stem cells and transformed leukemic cells. Cell Stem Cell 2008; 3:207-220.

2. Groschel S, Lugthart S, Schlenk R F, Valk P J, Eiwen K, Goudswaard C, van Putten W J, Kayser S, Verdonck L F, Lubbert M, Ossenkoppele G J, Germing U, SchmidtWolf I, Schlegelberger B, Krauter J, Ganser A, Dohner H, Lowenberg B, Dohner K, Delwel R. High EVI1 expression predicts outcome in younger adult patients with acute myeloid leukemia and is associated with distinct cytogenetic abnormalities. J Clin Oncol 2010; 28:2101-2107.

3. Lugthart S, van Drunen E, van Norden Y, van Hoven A, Erpelinck C A, Valk P J, Beverloo H B, Lowenberg B, Delwel R. High EVI1 levels predict adverse outcome in acute myeloid leukemia: prevalence of EVI1 overexpression and chromosome 3q26 abnormalities underestimated. Blood 2008; 111:4329-4337.
4. Valk P J, Verhaak R G, Beijen M A, Erpelinck C A, Barjesteh van Waalwijk van Doorn-Khosrovani $\mathrm{S}$, Boer J M, Beverloo H B, Moorhouse M J, van der Spek P J, Lowenberg B, Delwel R. Prognostically useful geneexpression profiles in acute myeloid leukemia. N Engl J Med 2004; 350:1617-1628.

5. Morishita K, Parganas E, William C L, Whittaker M H, Drabkin H, Oval J, Taetle R, Valentine M B, Ihle J N. Activation of EVI1 gene expression in human acute myelogenous leukemias by translocations spanning 300400 kilobases on chromosome band 3q26. Proc Natl Acad Sci U S A 1992; 89:3937-3941.

6. Ogawa S, Kurokawa M, Tanaka T, Mitani K, Inazawa J, Hangaishi A, Tanaka K, Matsuo Y, Minowada J, Tsubota T, Yazaki Y, Hirai H. Structurally altered Evi-1 protein generated in the 3q21q26 syndrome. Oncogene 1996; 13:183-191.

7. Arai S, Yoshimi A, Shimabe M, Ichikawa M, Nakagawa M, Imai Y, Goyama S, Kurokawa M. Evi-1 is a transcriptional target of MLL oncoproteins in hematopoietic stem cells. Blood;

8. De Weer A, Poppe B, Vergult S, Van Vlierberghe P, Petrick M, De Bock R, Benoit Y, Noens L, De Paepe A, Van Roy N, Menten B, Speleman F. Identification of two critically deleted regions within chromosome segment 7q35-q36 in EVI1 deregulated myeloid leukemia cell lines. PLoS One 2010; 5:e8676.

9. Izutsu K, Kurokawa M, Imai Y, Maki K, Mitani K, Hirai H. The corepressor CtBP interacts with Evi-1 to repress transforming growth factor beta signaling. Blood 2001; 97:2815-2822.

10. Kurokawa M, Mitani K, Irie K, Matsuyama T, Takahashi T, Chiba S, Yazaki Y, Matsumoto K, Hirai H. The oncoprotein Evi-1 represses TGF-beta signalling by inhibiting Smad3. Nature 1998; 394:92-96.

11. Kurokawa M, Mitani K, Yamagata T, Takahashi T, Izutsu K, Ogawa S, Moriguchi T, Nishida E, Yazaki Y, Hirai H. The evi-1 oncoprotein inhibits c-Jun N-terminal kinase and prevents stress-induced cell death. EMBO J 2000; 19:29582968.

12. Buonamici S, Li D, Mikhail F M, Sassano A, Platanias L C, Colamonici O, Anastasi J, Nucifora G. EVI1 abrogates interferon-alpha response by selectively blocking PML induction. J Biol Chem 2005; 280:428-436.

13. Yatsula B, Lin S, Read A J, Poholek A, Yates K, Yue D, Hui P, Perkins A S. Identification of binding sites of EVI1 in mammalian cells. J Biol Chem 2005; 280:30712-30722.

14. Yuasa H, Oike Y, Iwama A, Nishikata I, Sugiyama D, Perkins A, Mucenski M L, Suda T, Morishita K. Oncogenic transcription factor Evil regulates hematopoietic stem cell proliferation through GATA-2 expression. EMBO J 2005; 24:1976-1987.

15. Shimabe M, Goyama S, Watanabe-Okochi N, Yoshimi A, Ichikawa M, Imai Y, Kurokawa M. Pbx1 is a downstream 
target of Evi-1 in hematopoietic stem/progenitors and leukemic cells. Oncogene 2009; 28:4364-4374.

16. Ernst T, Chase A J, Score J, Hidalgo-Curtis C E, Bryant C, Jones A V, Waghorn K, Zoi K, Ross F M, Reiter A, Hochhaus A, Drexler H G, Duncombe A, Cervantes F, Oscier D, Boultwood J, Grand F H, Cross N C. Inactivating mutations of the histone methyltransferase gene EZH2 in myeloid disorders. Nat Genet 2010; 42:722-726.

17. Makishima H, Jankowska A M, Tiu R V, Szpurka H, Sugimoto Y, Hu Z, Saunthararajah Y, Guinta K, Keddache M A, Putnam P, Sekeres M A, Moliterno A R, List A F, McDevitt M A, Maciejewski J P. Novel homo- and hemizygous mutations in EZH2 in myeloid malignancies. Leukemia 2010; 24:1799-1804.

18. Nikoloski G, Langemeijer S M, Kuiper R P, Knops R, Massop M, Tonnissen E R, van der Heijden A, Scheele T N, Vandenberghe P, de Witte T, van der Reijden B A, Jansen J $\mathrm{H}$. Somatic mutations of the histone methyltransferase gene EZH2 in myelodysplastic syndromes. Nat Genet 2010; 42:665-667.

19. Walter M J, Ding L, Shen D, Shao J, Grillot M, McLellan M, Fulton R, Schmidt H, Kalicki-Veizer J, O’Laughlin M, Kandoth C, Baty J, Westervelt P, Dipersio J F, Mardis E R, Wilson R K, Ley T J, Graubert T A. Recurrent DNMT3A mutations in patients with myelodysplastic syndromes. Leukemia 2011;

20. Yan X J, Xu J, Gu Z H, Pan C M, Lu G, Shen Y, Shi J Y, Zhu Y M, Tang L, Zhang X W, Liang W X, Mi J Q, Song H D, Li K Q, Chen Z, Chen S J. Exome sequencing identifies somatic mutations of DNA methyltransferase gene DNMT3A in acute monocytic leukemia. Nat Genet 2011;

21. Ley T J, Ding L, Walter M J, McLellan M D, Lamprecht T, Larson D E, Kandoth C, Payton J E, Baty J, Welch J, Harris C C, Lichti C F, Townsend R R, Fulton R S, Dooling D J, Koboldt D C, Schmidt H, Zhang Q, Osborne J R, Lin L, O’Laughlin M, McMichael J F, Delehaunty K D, McGrath S D, Fulton L A, Magrini V J, Vickery T L, Hundal J, Cook L L, Conyers J J, Swift G W, Reed J P, Alldredge P A, Wylie T, Walker J, Kalicki J, Watson M A, Heath S, Shannon W D, Varghese N, Nagarajan R, Westervelt P, Tomasson M H, Link D C, Graubert T A, DiPersio J F, Mardis E R, Wilson R K. DNMT3A mutations in acute myeloid leukemia. N Engl J Med 2010; 363:2424-2433.

22. Delhommeau F, Dupont S, Della Valle V, James C, Trannoy S, Masse A, Kosmider O, Le Couedic J P, Robert F, Alberdi A, Lecluse Y, Plo I, Dreyfus F J, Marzac C, Casadevall N, Lacombe C, Romana S P, Dessen P, Soulier J, Viguie F, Fontenay M, Vainchenker W, Bernard O A. Mutation in TET2 in myeloid cancers. N Engl J Med 2009; 360:2289-2301.

23. Langemeijer S M, Kuiper R P, Berends M, Knops R, Aslanyan M G, Massop M, Stevens-Linders E, van Hoogen P, van Kessel A G, Raymakers R A, Kamping E J, Verhoef G E, Verburgh E, Hagemeijer A, Vandenberghe P, de Witte
T, van der Reijden B A, Jansen J H. Acquired mutations in TET2 are common in myelodysplastic syndromes. Nat Genet 2009; 41:838-842.

24. Gelsi-Boyer V, Trouplin V, Adelaide J, Bonansea J, Cervera N, Carbuccia N, Lagarde A, Prebet T, Nezri M, Sainty D, Olschwang S, Xerri L, Chaffanet M, Mozziconacci M J, Vey N, Birnbaum D. Mutations of polycomb-associated gene ASXL1 in myelodysplastic syndromes and chronic myelomonocytic leukaemia. Br J Haematol 2009; 145:788800 .

25. van Haaften G, Dalgliesh G L, Davies H, Chen L, Bignell G, Greenman C, Edkins S, Hardy C, O’Meara S, Teague J, Butler A, Hinton J, Latimer C, Andrews J, Barthorpe S, Beare D, Buck G, Campbell P J, Cole J, Forbes S, Jia M, Jones D, Kok C Y, Leroy C, Lin M L, McBride D J, Maddison M, Maquire S, McLay K, Menzies A, Mironenko T, Mulderrig L, Mudie L, Pleasance E, Shepherd R, Smith R, Stebbings L, Stephens P, Tang G, Tarpey P S, Turner R, Turrell K, Varian J, West S, Widaa S, Wray P, Collins V P, Ichimura K, Law S, Wong J, Yuen S T, Leung S Y, Tonon G, DePinho R A, Tai Y T, Anderson K C, Kahnoski R J, Massie A, Khoo S K, Teh B T, Stratton M R, Futreal P A. Somatic mutations of the histone H3K27 demethylase gene UTX in human cancer. Nat Genet 2009; 41:521-523.

26. Martin-Perez D, Piris M A, Sanchez-Beato M. Polycomb proteins in hematologic malignancies. Blood 2010; 116:5465-5475.

27. Yoshimi A, Kurokawa M. Key roles of histone methyltransferase and demethylase in leukemogenesis. J Cell Biochem 2011; 112:415-424.

28. Beisel C, Paro R. Silencing chromatin: comparing modes and mechanisms. Nat Rev Genet 2011; 12:123-135.

29. Bracken A P, Helin K. Polycomb group proteins: navigators of lineage pathways led astray in cancer. Nat Rev Cancer 2009; 9:773-784.

30. Margueron R, Reinberg D. The Polycomb complex PRC2 and its mark in life. Nature 2011; 469:343-349.

31. Sauvageau M, Sauvageau G. Polycomb group proteins: multi-faceted regulators of somatic stem cells and cancer. Cell Stem Cell 2010; 7:299-313.

32. Surface L E, Thornton S R, Boyer L A. Polycomb group proteins set the stage for early lineage commitment. Cell Stem Cell 2010; 7:288-298.

33. Yoshimi A, Goyama S, Watanabe-Okochi N, Yoshiki Y, Nannya Y, Nitta E, Arai S, Sato T, Shimabe M, Nakagawa M, Imai Y, Kitamura T, Kurokawa M. Evi1 represses PTEN expression and activates PI3K/AKT/mTOR via interactions with polycomb proteins. Blood 2011; 117:3617-3628.

34. Gutierrez N C, Lopez-Perez R, Hernandez J M, Isidro I, Gonzalez B, Delgado M, Ferminan E, Garcia J L, Vazquez L, Gonzalez M, San Miguel J F. Gene expression profile reveals deregulation of genes with relevant functions in the different subclasses of acute myeloid leukemia. Leukemia 2005; 19:402-409. 
35. Boukarabila H, Saurin A J, Batsche E, Mossadegh N, van Lohuizen M, Otte A P, Pradel J, Muchardt C, Sieweke M, Duprez E. The PRC1 Polycomb group complex interacts with PLZF/RARA to mediate leukemic transformation. Genes Dev 2009; 23:1195-1206.

36. Villa R, Pasini D, Gutierrez A, Morey L, Occhionorelli M, Vire E, Nomdedeu J F, Jenuwein T, Pelicci P G, Minucci S, Fuks F, Helin K, Di Croce L. Role of the polycomb repressive complex 2 in acute promyelocytic leukemia. Cancer Cell 2007; 11:513-525.

37. Lugthart S, Figueroa M E, Bindels E, Skrabanek L, Valk P J, Li Y, Meyer S, Erpelinck-Verschueren C, Greally J, Lowenberg B, Melnick A, Delwel R. Aberrant DNA hypermethylation signature in acute myeloid leukemia directed by EVI1. Blood 2011; 117:234-241.

38. Vire E, Brenner C, Deplus R, Blanchon L, Fraga M, Didelot C, Morey L, Van Eynde A, Bernard D, Vanderwinden J M, Bollen M, Esteller M, Di Croce L, de Launoit Y, Fuks F. The Polycomb group protein EZH2 directly controls DNA methylation. Nature 2006; 439:871-874.

39. Rea S, Eisenhaber F, O'Carroll D, Strahl B D, Sun Z W, Schmid M, Opravil S, Mechtler K, Ponting C P, Allis C $\mathrm{D}$, Jenuwein $\mathrm{T}$. Regulation of chromatin structure by site-specific histone H3 methyltransferases. Nature 2000; 406:593-599.

40. Tachibana M, Sugimoto K, Fukushima T, Shinkai Y. Set domain-containing protein, G9a, is a novel lysine-preferring mammalian histone methyltransferase with hyperactivity and specific selectivity to lysines 9 and 27 of histone H3. J Biol Chem 2001; 276:25309-25317.

41. Cattaneo F, Nucifora G. EVI1 recruits the histone methyltransferase SUV39H1 for transcription repression. J Cell Biochem 2008; 105:344-352.

42. Goyama S, Nitta E, Yoshino T, Kako S, Watanabe-Okochi N, Shimabe M, Imai Y, Takahashi K, Kurokawa M. EVI1 interacts with histone methyltransferases SUV39H1 and G9a for transcriptional repression and bone marrow immortalization. Leukemia 2010; 24:81-88.

43. Spensberger D, Delwel R. A novel interaction between the proto-oncogene Evil and histone methyltransferases, SUV39H1 and G9a. FEBS Lett 2008; 582:2761-2767.

44. Spensberger D, Vermeulen M, Le Guezennec X, Beekman R, van Hoven A, Bindels E, Stunnenberg H, Delwel R. Myeloid transforming protein Evil interacts with methylCpG binding domain protein 3 and inhibits in vitro histone deacetylation by Mbd3/Mi-2/NuRD. Biochemistry 2008; 47:6418-6426.

45. Vinatzer U, Taplick J, Seiser C, Fonatsch C, Wieser R. The leukaemia-associated transcription factors EVI-1 and MDS1/EVI1 repress transcription and interact with histone deacetylase. Br J Haematol 2001; 114:566-573.

46. Le Guezennec X, Vermeulen M, Brinkman A B, Hoeijmakers W A, Cohen A, Lasonder E, Stunnenberg H G. $\mathrm{MBD} 2 / \mathrm{NuRD}$ and $\mathrm{MBD} 3 / \mathrm{NuRD}$, two distinct complexes with different biochemical and functional properties. Mol Cell Biol 2006; 26:843-851.

47. Zhang Y, Ng H H, Erdjument-Bromage H, Tempst P, Bird A, Reinberg D. Analysis of the NuRD subunits reveals a histone deacetylase core complex and a connection with DNA methylation. Genes Dev 1999; 13:1924-1935.

48. Chi Y, Senyuk V, Chakraborty S, Nucifora G. EVI1 promotes cell proliferation by interacting with BRG1 and blocking the repression of BRG1 on E2F1 activity. J Biol Chem 2003; 278:49806-49811.

49. Dickstein J, Senyuk V, Premanand K, Laricchia-Robbio L, Xu P, Cattaneo F, Fazzina R, Nucifora G. Methylation and silencing of miRNA-124 by EVI1 and self-renewal exhaustion of hematopoietic stem cells in murine myelodysplastic syndrome. Proc Natl Acad Sci U S A 2010; 107:9783-9788.

50. Gomez-Benito M, Conchillo A, Garcia M A, Vazquez I, Maicas M, Vicente C, Cristobal I, Marcotegui N, GarciaOrti L, Bandres E, Calasanz M J, Alonso M M, Odero M D. EVI1 controls proliferation in acute myeloid leukaemia through modulation of miR-1-2. Br J Cancer 2010; 103:1292-1296.

51. Gao J S, Zhang Y, Tang X, Tucker L D, Tarwater P M, Quesenberry P J, Rigoutsos I, Ramratnam B. The Evi1, microRNA-143, K-Ras axis in colon cancer. FEBS Lett 2011; 585:693-699.

52. Sabatini D M. mTOR and cancer: insights into a complex relationship. Nat Rev Cancer 2006; 6:729-734.

53. Vivanco I, Sawyers C L. The phosphatidylinositol 3-Kinase AKT pathway in human cancer. Nat Rev Cancer 2002; 2:489-501.

54. Yuan T L, Cantley L C. PI3K pathway alterations in cancer: variations on a theme. Oncogene 2008; 27:5497-5510.

55. Watanabe-Okochi N, Kitaura J, Ono R, Harada H, Harada Y, Komeno Y, Nakajima H, Nosaka T, Inaba T, Kitamura T. AML1 mutations induced MDS and MDS/AML in a mouse BMT model. Blood 2008; 111:4297-4308.

56. Grisolano J L, O’Neal J, Cain J, Tomasson M H. An activated receptor tyrosine kinase, TEL/PDGFbetaR, cooperates with AML1/ETO to induce acute myeloid leukemia in mice. Proc Natl Acad Sci U S A 2003; 100:9506-9511.

57. Tamburini J, Elie C, Bardet V, Chapuis N, Park S, Broet P, Cornillet-Lefebvre P, Lioure B, Ugo V, Blanchet O, Ifrah N, Witz F, Dreyfus F, Mayeux P, Lacombe C, Bouscary D. Constitutive phosphoinositide 3-kinase/Akt activation represents a favorable prognostic factor in de novo acute myelogenous leukemia patients. Blood 2007; 110:10251028.

58. Xu Q, Simpson S E, Scialla T J, Bagg A, Carroll M. Survival of acute myeloid leukemia cells requires PI3 kinase activation. Blood 2003; 102:972-980.

59. Tamburini J, Green A S, Bardet V, Chapuis N, Park S, Willems L, Uzunov M, Ifrah N, Dreyfus F, Lacombe C, Mayeux P, Bouscary D. Protein synthesis is resistant to 
rapamycin and constitutes a promising therapeutic target in acute myeloid leukemia. Blood 2009; 114:1618-1627.

60. Liu T C, Lin P M, Chang J G, Lee J P, Chen T P, Lin S F. Mutation analysis of PTEN/MMAC1 in acute myeloid leukemia. Am J Hematol 2000; 63:170-175.

61. Luo J M, Yoshida H, Komura S, Ohishi N, Pan L, Shigeno K, Hanamura I, Miura K, Iida S, Ueda R, Naoe T, Akao Y, Ohno R, Ohnishi K. Possible dominant-negative mutation of the SHIP gene in acute myeloid leukemia. Leukemia $2003 ; 17: 1-8$

62. Cheong J W, Eom J I, Maeng H Y, Lee S T, Hahn J S, Ko Y W, Min Y H. Phosphatase and tensin homologue phosphorylation in the $\mathrm{C}$-terminal regulatory domain is frequently observed in acute myeloid leukaemia and associated with poor clinical outcome. Br J Haematol 2003; 122:454-456.

63. Min $\mathrm{Y} \mathrm{H}$, Eom $\mathrm{J} \mathrm{I}$, Cheong $\mathrm{J} \mathrm{W}$, Maeng $\mathrm{H} \mathrm{O}$, Kim $\mathrm{J}$ Y, Jeung H K, Lee S T, Lee M H, Hahn J S, Ko Y W. Constitutive phosphorylation of $\mathrm{Akt} / \mathrm{PKB}$ protein in acute myeloid leukemia: its significance as a prognostic variable. Leukemia 2003; 17:995-997.

64. Kornblau S M, Womble M, Qiu Y H, Jackson C E, Chen W, Konopleva M, Estey E H, Andreeff M. Simultaneous activation of multiple signal transduction pathways confers poor prognosis in acute myelogenous leukemia. Blood 2006; 108:2358-2365.

65. Gallay N, Dos Santos C, Cuzin L, Bousquet M, Simmonet Gouy V, Chaussade C, Attal M, Payrastre B, Demur C, Recher C. The level of AKT phosphorylation on threonine 308 but not on serine 473 is associated with high-risk cytogenetics and predicts poor overall survival in acute myeloid leukaemia. Leukemia 2009; 23:1029-1038.

66. Bardet $\mathrm{V}$, Tamburini $\mathrm{J}$, Ifrah $\mathrm{N}$, Dreyfus $\mathrm{F}$, Mayeux P, Bouscary D, Lacombe C. Single cell analysis of phosphoinositide 3-kinase/Akt and ERK activation in acute myeloid leukemia by flow cytometry. Haematologica 2006; 91:757-764

67. Yilmaz O H, Valdez R, Theisen B K, Guo W, Ferguson $\mathrm{D} \mathrm{O}, \mathrm{Wu} \mathrm{H}$, Morrison S J. Pten dependence distinguishes haematopoietic stem cells from leukaemia-initiating cells. Nature 2006; 441:475-482.

68. Zhang J, Grindley J C, Yin T, Jayasinghe S, He X C, Ross J T, Haug J S, Rupp D, Porter-Westpfahl K S, Wiedemann L M, Wu H, Li L. PTEN maintains haematopoietic stem cells and acts in lineage choice and leukaemia prevention. Nature 2006; 441:518-522.

69. Steelman L S, Abrams S L, Whelan J, Bertrand F E, Ludwig D E, Basecke J, Libra M, Stivala F, Milella M, Tafuri A, Lunghi P, Bonati A, Martelli A M, McCubrey J A. Contributions of the Raf/MEK/ERK, PI3K/PTEN/Akt/ mTOR and Jak/STAT pathways to leukemia. Leukemia 2008; 22:686-707.

70. McCubrey J A, Steelman L S, Abrams S L, Bertrand F E, Ludwig D E, Basecke J, Libra M, Stivala F, Milella M,
Tafuri A, Lunghi P, Bonati A, Martelli A M. Targeting survival cascades induced by activation of Ras/Raf/MEK/ ERK, PI3K/PTEN/Akt/mTOR and Jak/STAT pathways for effective leukemia therapy. Leukemia 2008; 22:708-722.

71. Maser R S, Choudhury B, Campbell P J, Feng B, Wong K K, Protopopov A, O’Neil J, Gutierrez A, Ivanova E, Perna I, Lin E, Mani V, Jiang S, McNamara K, Zaghlul S, Edkins S, Stevens C, Brennan C, Martin E S, Wiedemeyer R, Kabbarah O, Nogueira C, Histen G, Aster J, Mansour M, Duke V, Foroni L, Fielding A K, Goldstone A H, Rowe J M, Wang Y A, Look A T, Stratton M R, Chin L, Futreal P A, DePinho R A. Chromosomally unstable mouse tumours have genomic alterations similar to diverse human cancers. Nature 2007; 447:966-971.

72. Peng C, Chen Y, Li D, Li S. Role of Pten in leukemia stem cells. Oncotarget 2010; 1:156-160.

73. Peng C, Chen Y, Yang Z, Zhang H, Osterby L, Rosmarin A G, Li S. PTEN is a tumor suppressor in CML stem cells and BCR-ABL-induced leukemias in mice. Blood 2010; 115:626-635.

74. Sehgal S N. Rapamune (RAPA, rapamycin, sirolimus): mechanism of action immunosuppressive effect results from blockade of signal transduction and inhibition of cell cycle progression. Clin Biochem 1998; 31:335-340.

75. Sehgal S N. Sirolimus: its discovery, biological properties, and mechanism of action. Transplant Proc 2003; 35:7S-14S.

76. Zent C S, LaPlant B R, Johnston P B, Call T G, Habermann $\mathrm{T}$ M, Micallef I N, Witzig $\mathrm{T}$ E. The treatment of recurrent/refractory chronic lymphocytic leukemia/small lymphocytic lymphoma (CLL) with everolimus results in clinical responses and mobilization of CLL cells into the circulation. Cancer 2010; 116:2201-2207.

77. Witzig T E, Reeder C B, LaPlant B R, Gupta M, Johnston P B, Micallef I N, Porrata L F, Ansell S M, Colgan J P, Jacobsen E D, Ghobrial I M, Habermann T M. A phase II trial of the oral mTOR inhibitor everolimus in relapsed aggressive lymphoma. Leukemia 2011; 25:341-347.

78. Witzig T E, Geyer S M, Ghobrial I, Inwards D J, Fonseca R, Kurtin P, Ansell S M, Luyun R, Flynn P J, Morton R F, Dakhil S R, Gross H, Kaufmann S H. Phase II trial of single-agent temsirolimus (CCI-779) for relapsed mantle cell lymphoma. J Clin Oncol 2005; 23:5347-5356.

79. Haritunians T, Mori A, O'Kelly J, Luong Q T, Giles F J, Koeffler H P. Antiproliferative activity of RAD001 (everolimus) as a single agent and combined with other agents in mantle cell lymphoma. Leukemia 2007; 21:333339.

80. Teachey D T, Obzut D A, Cooperman J, Fang J, Carroll M, Choi J K, Houghton P J, Brown V I, Grupp S A. The mTOR inhibitor CCI-779 induces apoptosis and inhibits growth in preclinical models of primary adult human ALL. Blood 2006; 107:1149-1155.

81. Brown V I, Fang J, Alcorn K, Barr R, Kim J M, Wasserman $\mathrm{R}$, Grupp S A. Rapamycin is active against B-precursor 
leukemia in vitro and in vivo, an effect that is modulated by IL-7-mediated signaling. Proc Natl Acad Sci U S A 2003; 100:15113-15118.

82. Vaysberg M, Balatoni C E, Nepomuceno R R, Krams S M, Martinez O M. Rapamycin inhibits proliferation of EpsteinBarr virus-positive B-cell lymphomas through modulation of cell-cycle protein expression. Transplantation 2007; 83:1114-1121.

83. Sin S H, Roy D, Wang L, Staudt M R, Fakhari F D, Patel D D, Henry D, Harrington W J, Jr., Damania B A, Dittmer D P. Rapamycin is efficacious against primary effusion lymphoma (PEL) cell lines in vivo by inhibiting autocrine signaling. Blood 2007; 109:2165-2173.

84. Wanner K, Hipp S, Oelsner M, Ringshausen I, Bogner C, Peschel C, Decker T. Mammalian target of rapamycin inhibition induces cell cycle arrest in diffuse large B cell lymphoma (DLBCL) cells and sensitises DLBCL cells to rituximab. Br J Haematol 2006; 134:475-484.

85. Jundt F, Raetzel N, Muller C, Calkhoven C F, Kley K, Mathas S, Lietz A, Leutz A, Dorken B. A rapamycin derivative (everolimus) controls proliferation through down-regulation of truncated CCAAT enhancer binding protein $\{$ beta $\}$ and NF- kappa $\}$ B activity in Hodgkin and anaplastic large cell lymphomas. Blood 2005; 106:18011807.

86. Costa L J. Aspects of mTOR biology and the use of mTOR inhibitors in non-Hodgkin's lymphoma. Cancer Treat Rev 2007; 33:78-84.

87. Recher C, Beyne-Rauzy O, Demur C, Chicanne G, Dos Santos C, Mas V M, Benzaquen D, Laurent G, Huguet F, Payrastre B. Antileukemic activity of rapamycin in acute myeloid leukemia. Blood 2005; 105:2527-2534.

88. Antin J H, Kim H T, Cutler C, Ho V T, Lee S J, Miklos D B, Hochberg E P, Wu C J, Alyea E P, Soiffer R J. Sirolimus, tacrolimus, and low-dose methotrexate for graft-versushost disease prophylaxis in mismatched related donor or unrelated donor transplantation. Blood 2003; 102:16011605.

89. Benito A I, Furlong T, Martin P J, Anasetti C, Appelbaum F R, Doney K, Nash R A, Papayannopoulou T, Storb R, Sullivan K M, Witherspoon R, Deeg H J. Sirolimus (rapamycin) for the treatment of steroid-refractory acute graft-versus-host disease. Transplantation 2001; 72:19241929.

90. Couriel D R, Saliba R, Escalon M P, Hsu Y, Ghosh $\mathrm{S}$, Ippoliti $\mathrm{C}$, Hicks $\mathrm{K}$, Donato $\mathrm{M}$, Giralt $\mathrm{S}$, Khouri I F, Hosing C, de Lima M J, Andersson B, Neumann J, Champlin R. Sirolimus in combination with tacrolimus and corticosteroids for the treatment of resistant chronic graftversus-host disease. Br J Haematol 2005; 130:409-417.

91. Cutler C, Kim H T, Hochberg E, Ho V, Alyea E, Lee S J, Fisher D C, Miklos D, Levin J, Sonis S, Soiffer R J, Antin J H. Sirolimus and tacrolimus without methotrexate as graft-versus-host disease prophylaxis after matched related donor peripheral blood stem cell transplantation. Biol
Blood Marrow Transplant 2004; 10:328-336.

92. Cutler C, Li S, Ho V T, Koreth J, Alyea E, Soiffer R J, Antin J H. Extended follow-up of methotrexate-free immunosuppression using sirolimus and tacrolimus in related and unrelated donor peripheral blood stem cell transplantation. Blood 2007; 109:3108-3114.

93. Johnston L J, Brown J, Shizuru J A, Stockerl-Goldstein K E, Stuart M J, Blume K G, Negrin R S, Chao N J. Rapamycin (sirolimus) for treatment of chronic graft-versus-host disease. Biol Blood Marrow Transplant 2005; 11:47-55.

94. Jurado M, Vallejo C, Perez-Simon J A, Brunet S, Ferra C, Balsalobre P, Perez-Oteyza J, Espigado I, Romero A, Caballero D, Sierra J, Ribera J M, Diez J L. Sirolimus as part of immunosuppressive therapy for refractory chronic graft-versus-host disease. Biol Blood Marrow Transplant 2007; 13:701-706.

95. Armand P, Gannamaneni S, Kim H T, Cutler C S, Ho V T, Koreth J, Alyea E P, LaCasce A S, Jacobsen E D, Fisher D C, Brown J R, Canellos G P, Freedman A S, Soiffer R J, Antin J H. Improved survival in lymphoma patients receiving sirolimus for graft-versus-host disease prophylaxis after allogeneic hematopoietic stem-cell transplantation with reduced-intensity conditioning. J Clin Oncol 2008; 26:5767-5774.

96. Durakovic N, Radojcic V, Powell J, Luznik L. Rapamycin promotes emergence of IL-10-secreting donor lymphocyte infusion-derived $\mathrm{T}$ cells without compromising their graftversus-leukemia reactivity. Transplantation 2007; 83:631640.

97. Schleuning M, Judith D, Jedlickova Z, Stubig T, Heshmat M, Baurmann H, Schwerdtfeger R. Calcineurin inhibitorfree GVHD prophylaxis with sirolimus, mycophenolate mofetil and ATG in Allo-SCT for leukemia patients with high relapse risk: an observational cohort study. Bone Marrow Transplant 2009; 43:717-723.

98. Marty F M, Bryar J, Browne S K, Schwarzberg T, Ho V T, Bassett I V, Koreth J, Alyea E P, Soiffer R J, Cutler C S, Antin J H, Baden L R. Sirolimus-based graft-versushost disease prophylaxis protects against cytomegalovirus reactivation after allogeneic hematopoietic stem cell transplantation: a cohort analysis. Blood 2007; 110:490500.

99. Cutler C, Stevenson K, Kim H T, Richardson P, Ho V T, Linden E, Revta C, Ebert R, Warren D, Choi S, Koreth J, Armand P, Alyea E, Carter S, Horowitz M, Antin J H, Soiffer R. Sirolimus is associated with veno-occlusive disease of the liver after myeloablative allogeneic stem cell transplantation. Blood 2008; 112:4425-4431.

100. Platzbecker U, von Bonin M, Goekkurt E, Radke J, Binder M, Kiani A, Stoehlmacher J, Schetelig J, Thiede C, Ehninger G, Bornhauser M. Graft-versus-host disease prophylaxis with everolimus and tacrolimus is associated with a high incidence of sinusoidal obstruction syndrome and microangiopathy: results of the EVTAC trial. Biol Blood Marrow Transplant 2009; 15:101-108. 
101. Kuendgen A, Gattermann N. Valproic acid for the treatment of myeloid malignancies. Cancer 2007; 110:943-954.

102. Lane A A, Chabner B A. Histone deacetylase inhibitors in cancer therapy. J Clin Oncol 2009; 27:5459-5468.

103. Issa J P. Optimizing therapy with methylation inhibitors in myelodysplastic syndromes: dose, duration, and patient selection. Nat Clin Pract Oncol 2005; 2 Suppl 1:S24-29.

104. Plimack E R, Kantarjian H M, Issa J P. Decitabine and its role in the treatment of hematopoietic malignancies. Leuk Lymphoma 2007; 48:1472-1481.

105. Kuendgen A, Lubbert M. Current status of epigenetic treatment in myelodysplastic syndromes. Ann Hematol 2008; 87:601-611.

106. Song L B, Li J, Liao W T, Feng Y, Yu C P, Hu L J, Kong Q L, Xu L H, Zhang X, Liu W L, Li M Z, Zhang L, Kang T B, Fu L W, Huang W L, Xia Y F, Tsao S W, Li M, Band V, Band H, Shi Q H, Zeng Y X, Zeng M S. The polycomb group protein Bmi-1 represses the tumor suppressor PTEN and induces epithelial-mesenchymal transition in human nasopharyngeal epithelial cells. J Clin Invest 2009; 119:3626-3636.

107. Bei J X, Li Y, Jia W H, Feng B J, Zhou G, Chen L Z, Feng Q S, Low H Q, Zhang H, He F, Tai E S, Kang T, Liu E T, Liu J, Zeng Y X. A genome-wide association study of nasopharyngeal carcinoma identifies three new susceptibility loci. Nat Genet 2010; 42:599-603.

108. Jazaeri A A, Ferriss J S, Bryant J L, Dalton M S, Dutta A. Evaluation of EVI1 and EVI1s (Delta324) as potential therapeutic targets in ovarian cancer. Gynecol Oncol 2010; 118:189-195.

109. Liu Y, Chen L, Ko T C, Fields A P, Thompson E A. Evi1 is a survival factor which conveys resistance to both TGFbetaand taxol-mediated cell death via PI3K/AKT. Oncogene 2006; 25:3565-3575.

110. Massion P P, Kuo W L, Stokoe D, Olshen A B, Treseler P A, Chin K, Chen C, Polikoff D, Jain A N, Pinkel D, Albertson D G, Jablons D M, Gray J W. Genomic copy number analysis of non-small cell lung cancer using array comparative genomic hybridization: implications of the phosphatidylinositol 3-kinase pathway. Cancer Res 2002; 62:3636-3640.

111. Nowee M E, Snijders A M, Rockx D A, de Wit R M, Kosma V M, Hamalainen K, Schouten J P, Verheijen R H, van Diest P J, Albertson D G, Dorsman J C. DNA profiling of primary serous ovarian and fallopian tube carcinomas with array comparative genomic hybridization and multiplex ligation-dependent probe amplification. J Pathol 2007; 213:46-55.

112. Engelman J A. Targeting PI3K signalling in cancer: opportunities, challenges and limitations. Nat Rev Cancer 2009; 9:550-562.

113. Liu P, Cheng H, Roberts T M, Zhao J J. Targeting the phosphoinositide 3-kinase pathway in cancer. Nat Rev Drug Discov 2009; 8:627-644.
114. Wong K K, Engelman J A, Cantley L C. Targeting the PI3K signaling pathway in cancer. Curr Opin Genet Dev 2010; 20:87-90.

115. Bleau A M, Hambardzumyan D, Ozawa T, Fomchenko E I, Huse J T, Brennan C W, Holland E C. PTEN/PI3K/ Akt pathway regulates the side population phenotype and ABCG2 activity in glioma tumor stem-like cells. Cell Stem Cell 2009; 4:226-235.

116. Dubrovska A, Kim S, Salamone R J, Walker J R, Maira S M, Garcia-Echeverria C, Schultz P G, Reddy V A. The role of PTEN/Akt/PI3K signaling in the maintenance and viability of prostate cancer stem-like cell populations. Proc Natl Acad Sci U S A 2009; 106:268-273.

117. Eyler C E, Foo W C, LaFiura K M, McLendon R E, Hjelmeland A B, Rich J N. Brain cancer stem cells display preferential sensitivity to Akt inhibition. Stem Cells 2008; 26:3027-3036.

118. Gallia G L, Tyler B M, Hann C L, Siu I M, Giranda V L, Vescovi A L, Brem H, Riggins G J. Inhibition of Akt inhibits growth of glioblastoma and glioblastoma stem-like cells. Mol Cancer Ther 2009; 8:386-393.

119. Guertin D A, Stevens D M, Saitoh M, Kinkel S, Crosby K, Sheen J H, Mullholland D J, Magnuson M A, Wu H, Sabatini D M. mTOR complex 2 is required for the development of prostate cancer induced by Pten loss in mice. Cancer Cell 2009; 15:148-159. 